\title{
Rivers and river basin management issues and concerns in the Pacific Northwest, USA
}

\author{
R. L. Mahler ${ }^{1} \&$ M. E. Barber ${ }^{2}$ \\ ${ }^{1}$ Soil Science Division, University of Idaho, USA \\ ${ }^{2}$ Department of Civil and Environmental \\ Engineering, University of Utah, USA
}

\begin{abstract}
Over $90 \%$ of Pacific Northwest residents consider clean rivers and effective river basin management to be important issues in the Pacific Northwest. The large Columbia-Snake River Basin provides irrigation water to 5,000,000 ha, water for navigation, drinking water to more than 5,000,000 people and electricity (hydropower) to more than $8,000,000$ people within Washington, Idaho, Oregon and British Columbia. The purpose of this paper is to document public perceptions, attitudes, and concerns about the Columbia-Snake River Basin. Two identical statistically designed regional surveys were conducted in 2011 and 2014. Approximately 98, 98, 90, 80, 80 and 54\% of the survey respondents considered the Columbia-Snake System important for providing water for mountain snowpack, power generation, agriculture, recreation, drinking, and commerce, respectively. A majority of the public also rated quality and quantity aspects of the river system as good or excellent. A majority of residents in 2011 (52.0\%) and $2014(62.1 \%)$ felt that climate change should be addressed regardless of cost. The percentage of survey respondents that believed scientific merit of climate change to be good or overwhelming increased from $47.1 \%$ in 2011 to $71.1 \%$ in 2014 . The loss of mountain snowpack was the most frequently cited critical issue associated with climate change in the Columbia-Snake River Basin.

Keywords: public concerns, public opinion, Columbia River Basin, water quality, water quantity.
\end{abstract}




\section{Introduction}

The Columbia-Snake River Basin has a large economic impact in both Canada and the USA. This system is key to the economies of British Columbia, Washington, Idaho and Oregon as it supports agriculture (5,000,000 irrigated ha), commerce, power production, direct human water consumption, food processing and recreation. Previously conducted surveys of the public have shown than that people are concerned about both water quality and water quantity issues within this large river basin [1-3].

\section{Background}

Even though river basin planning and management has occurred in most regions of the world over the last 85 years, results have often been disappointing [4]. Results have often fallen short of goals because many approaches have failed to be adequately integrated [5]. At times the failures of sound and effective institutional arrangements have also reduced the effectiveness of such programs [6]. Many times programs sold as integrated have failed to be comprehensive. To be both comprehensive and interdisciplinary the plan framework must include economic, technical, environmental, social and legal aspects $[7,8]$. The concept of river basin and river basin management has changed significantly over time [9]. For instance, international river basin treaties have largely focused on water use and water quantity issues; however, water quality aspects have become much more important in recent years [10].

More recently considerations about potential climate change and participatory management have become points of focus for river basin and management plans. Issues including the impact of changing climate on forests, range and other biomes is now an important planning consideration $[11,12]$. Others suggest that because of projected climate change river basins significantly impacted by dams will require more intervention to protect people than in basins with free-flowing rivers [13].

The importance of social learning in water resource management and sustainability science is increasing [14]. Eight commonly reported themes important in social learning identified by researchers include: (1) role of stakeholder involvement, (2) politics and institutions, (3) opportunities for interaction, (4) representativeness, (5) framing and refining, (6) motivation and skills of leaders and facilitators, (7) openness and transparency, and (8) adequate resources $[15,16]$. In addition to these themes computer decision support tools for participatory management are also important [17]. In addition to data analysis these support tools also enhance communication, forecasting, experimentation and training.

The three most important issues in the last decade in the Columbia-Snake River System include: (1) the impact of climate change on water management, (2) fish migration and management, and (3) trans-boundary water management. Several studies have suggested that climate change models indicate that the quantity of mountain snow and the timing of its melt will impact reservoir storage, shipping 
commerce and water available for irrigated agriculture [11]. Both dams and the associated production of hydroelectricity have in the past and will continue to impact fish populations and fish migration in the river system. In addition transboundary water management issues are currently being renegotiated, as treaties need to be revised and signed between Canada and the USA in the next few years. These three issues along with other interests have kept the public in the region aware of the importance of water management in this river system $[1-3,18]$.

The purpose of this paper is to document public perceptions, attitudes, concerns and actions taken to protect river resources in the region. Public input has been sought on a regular basis $(2002,2007,2012$ and 2014) to identify major river issues. Statistically designed regional surveys were the instruments used to identify the river issues of most concern to the public. A map of the ColumbiaSnake River System is shown in Figure 1.

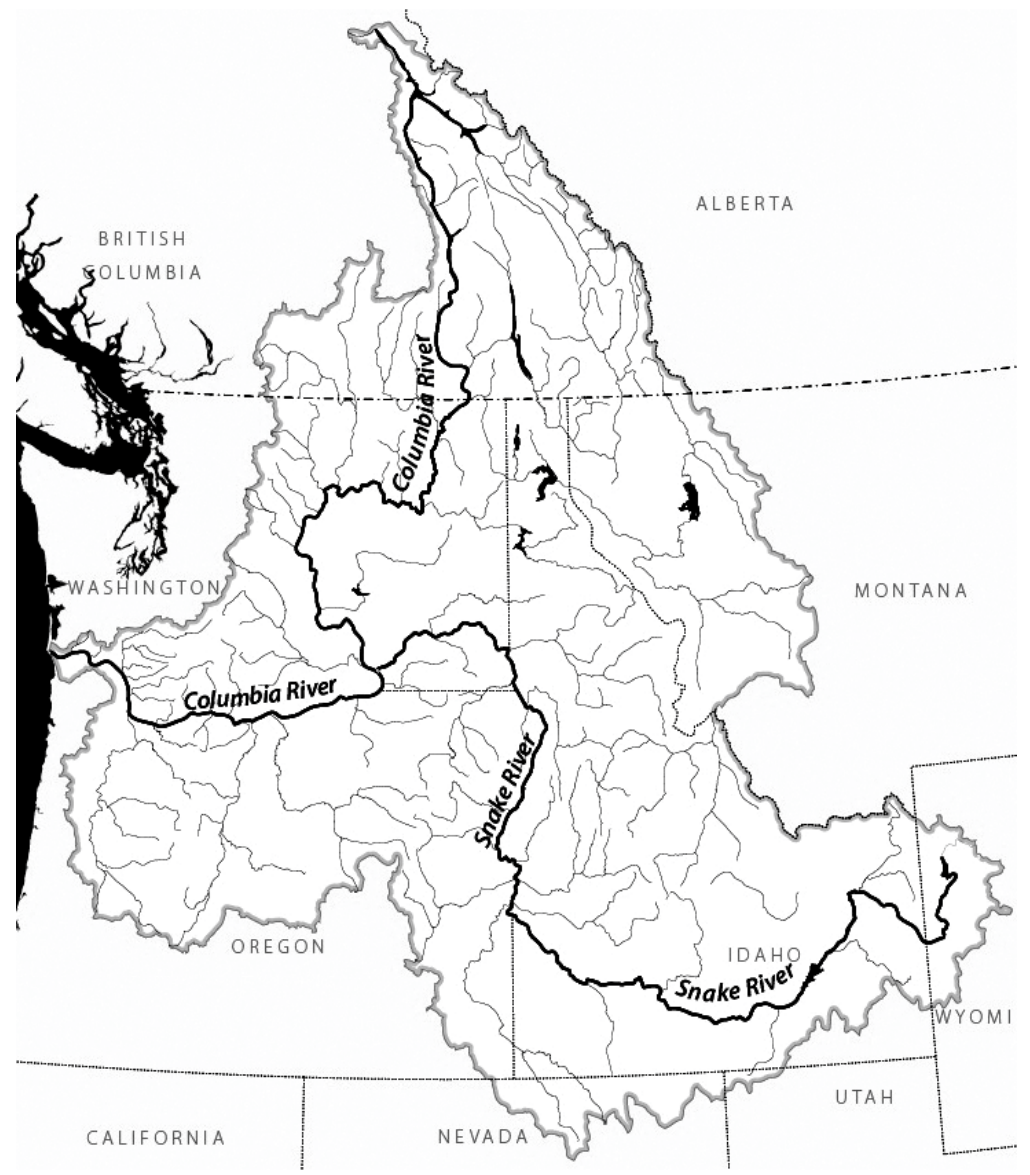

Figure 1: Map of the Columbia-Snake River Basin (courtesy of the Columbia River Inter-Tribal Fish Commission, Portland, OR, USA). 


\section{Methodology}

A survey instrument containing 40 questions was developed to access public attitudes, priorities and concerns about water resource issues, river management and the potential impacts of climate change in the Pacific Northwest. The same survey was administered to the general public in 2011 and 2014 to evaluate changes over time because there was a perception that public attitudes about climate change have been rapidly changing. The survey questions discussed in this article deal with activities that the public associate with river basin management and the potential impacts of climate change. The survey target audience was a representative sample of the 8,000,000 adult residents of Idaho, Oregon and Washington that live within the Columbia-Snake River Basin or highly dependent on its waters. In addition, demographic information, including state of residence, community size, and length of time residing in the region, gender, age, and educational level were also collected from survey respondents.

In both 2011 and 2014 a target of 1,000 completed questionnaires was chosen as the survey goal to result in a sampling error of 4 to $6 \%$ [19]. The survey process was designed to receive a completed survey return rate in excess of $50 \%$. Addresses were obtained from a professional social sciences survey company (SSI, Norwich, CT). Four mailings were planned to achieve the $50 \%$ return rate [20]. The mailing strategy used was identical to other water resource surveys that had been conducted in the region since 2002 [1-3].

Surveys were actually sent to 2,300 residents in both 2011 and 2014; however, because of address changes, deaths of people on the mailing list and delivery problems, the actual sample population was 2,116 in 2011 and 2,074 in 2014. The survey process was designed to receive a completed survey return rate in excess of $50 \%$. If more than 943 surveys were returned completed, sampling error could be assumed to be less than 5\% [19-21].

It only took three mailings were to achieve this target return rate of $50 \%$ in both 2011 and 2014. The first mailing included the water issues survey form, a business reply envelope, and a cover letter that: (1) identified the survey's authors; (2) explained the purpose of the survey; (3) assured the respondent of anonymity; and (4) asked the respondents to fill out and return the survey via the business reply envelope. The second mailing (four weeks later) consisted of a postcard that stressed the importance of the survey and remind the respondent to fill out and return the survey sent out in the first mailing. Five weeks later the third mailing was sent to residents who did not respond to the first or second mailing. This mailing included a reminder letter, another copy of the water issues survey, and a business reply envelope.

Survey answers were coded and entered into Microsoft Excel. Missing data were excluded from the analysis. The data were analysed at two levels using SAS [21]. The first level of analysis generated frequencies, while the second level evaluated the impacts of demographic factors. Significance $(\mathrm{P}<0.05)$ to demographic factors was tested using a chi-square distribution [19-21]. Similar response rates were observed for the 2011 and 2014 surveys and consequently data analyses procedures were identical in both years. 


\section{Results and discussion}

The survey methodology used in the study was not designed to be unique, but rather to be used as a tool to ascertain useful information. The survey methodology was designed to access public attitudes, priorities and concerns about water resource issues, river management and the potential impacts of climate change in the Pacific Northwest.

The 2011 River Basin Management Survey achieved a return rate of $51.1 \%$ (1,081 either fully or partially completed and returned out of 2,116$) .52 \%$ of the survey respondents were male. Over $37 \%$ of survey respondents lived in communities of more than 100,000 people. Conversely, $17 \%$ of respondents lived in towns with less than 7,000 people. $89 \%$ of survey respondents were high school graduates.

A return rate of $53.3 \%(1,106$ either fully or partially completed and returned out of 2,074) was achieved with the 2014 survey. Over 39\% of survey respondents lived in communities of more than 100,000 people. Conversely, $18 \%$ of respondents lived in towns with less than 7,000 people. $53 \%$ of the survey respondents were male. $86 \%$ of survey respondents were high school graduates.

Overall, the demographics of the respondents for both surveys closely reflected the actual demographics of adults in the region. Consequently, when coupled with the low sampling error of the survey, respondents are often equated to residents in the following discussion.

\subsection{Benefits of the Columbia-Snake system}

A majority of surveyed residents felt that the Columbia-Snake River System provided many benefits (Table 1). When the results of the 2011 and 2014 surveys were combined and the responses of very important and important were added together it was apparent that the public places a high value on the river system. Approximately 98, 98, 90, 80, 80 and $54 \%$ of the survey respondents considered the Columbia-Snake System important for providing water for mountain snowpack, power generation, agriculture, recreation, drinking, and commerce, respectively (Table 1).

Table 1: The importance of the Columbia-Snake River System in providing the following benefits to residents of the region based on the 2011 and 2014 basin surveys. Note that the results from both surveys are combined.

\begin{tabular}{lcccc}
\hline Benefit provided & $\begin{array}{c}\text { Very } \\
\text { Important }\end{array}$ & $\begin{array}{c}\text { Not } \\
\text { Important }\end{array}$ & $\begin{array}{c}\text { No } \\
\text { Important }\end{array}$ & Opinion \\
\hline Mountain snowpack & 95 & 3 & 0 & 1 \\
Power generation & 84 & 14 & 2 & 2 \\
Agriculture & 60 & 30 & 7 & 3 \\
Recreation & 51 & 29 & 16 & 4 \\
Drinking & 20 & 60 & 8 & 12 \\
Commerce & 10 & 44 & 40 & 6 \\
\hline
\end{tabular}


The public also had favorable views on the quality and quantity aspects of the Columbia-Snake River System (Tables 2 and 3). When the good and excellent water quality responses were added together over 55\% of respondents in 2011 and $57 \%$ of the 2014 respondents viewed the quality of waters in the river system favorably (Table 2). Conversely, only about $10 \%$ of the public in both 2011 and 2014 considered water quality poor.

Table 2: Public views about the quality of surface waters (rivers) in the Columbia-Snake River System based on the 2011 and 2014 basin surveys.

\begin{tabular}{lcc}
\hline Quality of surface waters & 2011 survey & 2014 survey \\
\hline \multirow{2}{*}{ Excellent } & 31.4 & 28.7 \\
Good & 23.9 & 29.2 \\
Fair & 19.7 & 17.2 \\
Poor & 10.3 & 9.6 \\
No opinion & 14.7 & 15.3 \\
\hline
\end{tabular}

Table 3: Public views about the sufficiency (quantity) of surface waters (rivers) in the Columbia-Snake River System to meet regional needs based on the 2011 and 2014 basin surveys.

\begin{tabular}{|c|c|c|}
\hline Quantity of surface waters & 2011 survey & 2014 survey \\
\hline & \multicolumn{2}{|c|}{--------------------- \% } \\
\hline More than adequate & 52.6 & 55.4 \\
\hline Adequate & 16.3 & 13.5 \\
\hline Somewhat less than adequate & 12.5 & 13.4 \\
\hline Much less than adequate & 4.8 & 4.6 \\
\hline No opinion & 14.8 & 13.1 \\
\hline
\end{tabular}

The majority of the public felt that the river system provided enough water to meet quantity needs in the region (Table 3 ). Over $68 \%$ of the public in both surveys felt that water quantity was adequate or more than adequate for human needs. Conversely, less than $5 \%$ of respondents in both surveys considered water quantity supplies to be much less than adequate.

\subsection{Most important benefit}

Even though the public identified many benefits provided by the Columbia-Snake River System, when asked to identify the most important benefit there was a strong consensus. Over $60 \%$ of the public in both 2011 and 2014 identified power production as the most important benefit provided by this river system (Table 4). Following power production, recreation, drinking water and food production were each cited by approximately $10 \%$ of the survey respondents. 
Table 4: Public perception of the most important benefit of the Columbia-Snake River System based on the 2011 and 2014 basin surveys.

\begin{tabular}{lcc}
\hline Most important benefit & 2011 survey & 2014 survey \\
\hline & ---10.6 & 63.0 \\
Power production & 14.2 & 13.5 \\
Recreation & 10.5 & 9.3 \\
Drinking water & 10.0 & 8.3 \\
Food production (agriculture) & 2.2 & 3.0 \\
Transportation/commerce & 2.0 & 2.1 \\
Fisheries & 1.1 & 0.8 \\
Other & & \\
\hline
\end{tabular}

\subsection{Impact of Climate Change}

Climate change has become an important topic in basin management studies. Pacific Northwest residents consider this issue important. In fact a majority of residents in $2011(52.0 \%)$ and 2014 (62.1\%) felt that climate change should be addressed regardless of cost (Table 5). In addition another 14.8\% (2011) and $13.4 \%$ (2014) of residents thought that climate change should be addressed if the financial cost is not too great. It should be noted that the importance of this issue increased significantly between 2011 and 2014. Both gender (Table 6) and education level (Table 7) impacted how the public viewed climate change.

Table 5: The importance of climate change as an issue based on the 2011 and 2014 Basin surveys.

\begin{tabular}{|c|c|c|}
\hline Importance of climate change & 2011 survey & 2014 survey \\
\hline & \multicolumn{2}{|c|}{--------------------- \% } \\
\hline Important, should address & 52.0 & 62.1 \\
\hline Important, should address if economical & 14.8 & 13.4 \\
\hline Don't know & 20.3 & 14.3 \\
\hline Not important, should not address & 12.9 & 10.2 \\
\hline
\end{tabular}

Table 6: The impact of gender on respondents indicating that climate change is an important issue that must be addressed based on the 2011 and 2014 Basin surveys.

\begin{tabular}{|c|c|c|}
\hline Gender & 2011 survey & 2014 survey \\
\hline & \multicolumn{2}{|c|}{ 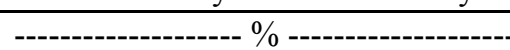 } \\
\hline Male & 43.5 & 46.5 \\
\hline Female & 61.5 & 74.8 \\
\hline All combined & 52.0 & 61.4 \\
\hline
\end{tabular}


Table 7: The impact of formal education level on respondents indicating that climate change is an important issue that must be addressed based on the 2011 and 2014 basin surveys.

\begin{tabular}{|c|c|c|}
\hline Formal education level & 2011 survey & 2014 survey \\
\hline & \multicolumn{2}{|c|}{ 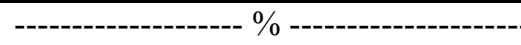 } \\
\hline Less than high school diploma & 36.6 & 37.2 \\
\hline High school diploma & 40.9 & 46.6 \\
\hline Some college & 52.7 & 61.8 \\
\hline College BA or BS & 57.7 & 66.0 \\
\hline Advance college degree & 63.9 & 78.5 \\
\hline
\end{tabular}

Females were more likely to cite climate change as an important issue that should be addressed than males (Table 7). In fact this difference due to gender actually increased with time (2011 vs. 2014). Education level also impacted the importance of addressing climate change. Increasing levels of formal education increased the desire to address climate change as an important issue in both survey years (Table 7).

The percentage of survey respondents that believed in the scientific merit of predicting climate change is good or overwhelming increased from $47.1 \%$ in 2011 to $71.1 \%$ in 2014 (Table 8 ). This data indicates that climate change became more accepted by people in the region over time. Conversely, less than $10 \%$ of survey respondents believe that the scientific evidence behind climate change is not compelling.

Table 8: Public attitudes toward the merit of scientific arguments that predict climate change based on the 2011 and 2014 basin surveys.

\begin{tabular}{lcc}
\hline How compelling is the science? & 2011 survey & 2014 survey \\
\hline & & \\
Overwhelming & 15.3 & 20.4 \\
Good & 31.8 & 50.7 \\
Don't know & 14.3 & 10.3 \\
Scientific community is in disarray & 29.0 & 12.6 \\
The science is not compelling & 9.6 & 6.0 \\
\hline
\end{tabular}

Residents identified many things that would be negatively impacted by climate change (Table 9). Based on the 2014 survey 59.4, 39.2, 36.1, 35.9 and 32.5\% of residents felt that the loss of mountain snowpack, reduced water for hydropower, reduced levels of groundwater, reduced river flows and loss of soil moisture for agriculture were important issues associated with climate change, respectively (Table 9). 
Table 9: The issues cited by residents that would be impacted by climate change in the Pacific Northwest based on the 2011 and 2014 basin surveys.

\begin{tabular}{lcc}
\hline Issue of concern & 2011 survey & 2014 survey \\
\hline & 51.4 & 59.4 \\
Loss of mountain snowpack & 26.5 & 39.2 \\
Reduced water for hydropower & 32.8 & 36.1 \\
Reduced levels of groundwater & 21.4 & 35.9 \\
Reduced river flows & 33.0 & 32.5 \\
Loss of soil moisture for agriculture & 27.0 & 29.4 \\
Sea level rise & 26.0 & 28.3 \\
Decline in forests (warm/dry summers) & 15.6 & 18.4 \\
Reduced fish stocks & 14.7 & 15.6 \\
Reduced water in private wells & 9.0 & 11.4 \\
Increased winter flooding & 10.1 & 8.6 \\
Reduced water for economic development & 3.3 & 6.9 \\
Reduced recreational activities & & \\
\hline
\end{tabular}

When residents were restricted to citing only one impact of climate change the loss of mountain snowpack was cited most often (Table 10 ). Over $25 \%$ of survey respondents in 2011 and 2014 cited loss of mountain snowpack as the most critical issue. Sea level rise, reduced levels of groundwater and reduced water for hydropower production were cited as the issue of most concern by between 9.7 and $16.8 \%$ of survey respondents.

Table 10: The issue of most concern cited by residents that would be impacted by climate change in the Pacific Northwest based on the 2011 and 2014 basin surveys.

\begin{tabular}{|c|c|c|}
\hline Issue of most concern & 2011 survey & 2014 survey \\
\hline & \multicolumn{2}{|c|}{----------------- \% \% Citing------------------- } \\
\hline Loss of mountain snowpack & 25.3 & 28.3 \\
\hline Sea level rise & 12.5 & 16.8 \\
\hline Reduced levels of groundwater & 14.1 & 12.6 \\
\hline Reduced water for hydropower & 9.7 & 12.4 \\
\hline Loss of soil moisture for agriculture & 9.4 & 7.2 \\
\hline Reduced river flows & 4.9 & 6.0 \\
\hline Decline in forests (warm/dry summers) & 6.0 & 4.8 \\
\hline Reduced water in private wells & 5.0 & 3.8 \\
\hline Increased winter flooding & 3.0 & 3.4 \\
\hline Reduced fish stocks & 3.3 & 3.0 \\
\hline Reduced water for economic development & 5.1 & 1.0 \\
\hline Reduced recreational activities & 1.0 & 0.6 \\
\hline Other & 0.7 & 0.2 \\
\hline
\end{tabular}


Homeowner concerns about climate change increased between 2011 and 2014. Homeowners were most concerned about the prospects of increasing power rates (hydropower more expensive), the increasing frequency of summer droughts, and more winter and spring flooding in urban areas. It is noteworthy that the urban public has been thinking about how climate change could impact their lives from a homeowner viewpoint.

\section{Conclusions and recommendations}

Residents of Idaho, Oregon and Washington appreciate the benefits provided by the Columbia-Snake River Basin in the Pacific Northwest. These benefits have both direct and indirect positive impacts on all residents of this region. The public has positive views on both the quality and quantity of water in the river system. Residents understand that climate change is an issue that can have many multiple negative impacts on both people and on ecosystems in the region. Key findings of this study include:

- Approximately 98, 98, 90, 80, 80 and 54\% of the survey respondents considered the Columbia-Snake System important for providing water for mountain snowpack, power generation, agriculture, recreation, drinking, and commerce, respectively.

- $\quad$ Over 55\% of respondents in 2011 and 57\% of the 2014 respondents viewed the quality of waters in the river system favorably.

- $\quad$ Over $68 \%$ of the public in both surveys felt that water quantity was adequate or more than adequate for human needs.

- Over $60 \%$ of the public in both 2011 and 2014 identified power production as the most important benefit provided by this river system.

- A majority of residents in 2011 (52.0\%) and 2014 (62.1\%) felt that climate change should be addressed regardless of cost.

- $\quad$ The percentage of survey respondents that believed the scientific merit predicting climate change is good or overwhelming increased from $47.1 \%$ in 2011 to $71.1 \%$ in 2014 .

- Approximately 59, 39, 36, 36 and 33\% of residents felt that the loss of mountain snowpack, reduced water for hydropower, reduced levels of groundwater, reduced river flows and loss of soil moisture for agriculture were important issues associated with climate change, respectively.

- The loss of mountain snowpack was the most frequently cited critical issue associated with climate change in the Columbia-Snake River Basin.

- Homeowners were most concerned about the prospects of increasing power rates (hydropower more expensive), the increasing frequency of summer droughts, and more winter and spring flooding in urban areas.

This survey study will be again conducted in 2017 to continue the evaluation of public attitudes and beliefs over time about the usefulness and management of the Columbia-Snake River Basin in the Pacific Northwest. 


\section{References}

[1] Mahler, R. L., Simmons, R., Sorensen, F., \& Miner, J.R., Priority water issues in the Pacific Northwest, Journal of Extension (Online), 42(5). Article 5RIB3. Available at: http://www.joe.org/joe/2004october/rb3.php, 2004.

[2] Mahler, R.L., Gamroth, M., Pearson, P., Sorenson, F., Barber, M.E. \& Simmons, R., Information sources, learning opportunities and priority water issues in the Pacific Northwest, Journal of Extension (Online), 48(2). Article 2RIB2. Available at: http://www.joe.org/joe/2010april/rb2.php, 2010.

[3] Mahler, R. L., Simmons, R., \& Sorensen, F., Drinking water issues in the Pacific Northwest. Journal of Extension, 43(6): 6RIB6, online at: http://www.joe.org/joe/2005december/rb6.php 2005.

[4] Barrow, Christopher J., River basin development planning and management: a critical review. World Development 26, No. 1: pp. 171-186, 1998.

[5] Downs, Peter W., Gregory, Kenneth J. \& Brookes, Andrew, How integrated is river basin management? Environmental management 15, No. 3: pp. 299309, 1991.

[6] Blomquist, William A., Dinar, Ariel, \& Kemper, Karin, Comparison of institutional arrangements for river basin management in eight basins. World Bank Policy Research Working Paper 3636, 2005.

[7] Cai, Ximing, McKinney, Daene C., \& Lasdon, Leon S., Integrated hydrologic-agronomic-economic model for river basin management. Journal of Water Resources Planning and Management 129, No. 1: pp. 417, 2003.

[8] McIver, James, \& Starr, Lynn, Restoration of degraded lands in the interior Columbia River basin: passive vs. active approaches. Forest Ecology and Management 153: pp. 15-28, 2001.

[9] Molle, Francois, River-basin planning and management: the social life of a concept. Geoforum 40: pp. 484-494, 2009.

[10] Shmueli, Deborah F., Water quality in international river basins. Political Geography 18: pp. 437-476, 1999.

[11] Cohen, Stewart J., Miller, Kathleen A., Hamlet, Alan F. \& Avis, Wendy, Climate change and resource management in the Columbia River basin. Water International 25: pp. 253-272, 2000.

[12] Payne, J.T., Wood, A.W. \& Hamlet, A. F., Mitigating the effect of climate change on water resources of the Columbia River basin. Climate Change 62: pp. 233-256, 2004.

[13] Palmer, Margaret A., Reidy Liermann, Catherine A., Nilsson, Christer, Flörke, Martina, Alcamo, Joseph, Lake, P. Sam \& Bond, Nick, Climate change and the world's river basins: anticipating management options. Frontiers in Ecology and the Environment 6 (2): pp. 81-89, 2008. 
[14] Pahl-Wostl, Claudia, Mostert, Erik \& Tàbara, David, The growing importance of social learning in water resources management and sustainability science. Ecology and Society, 13(1), 2008.

[15] Mostert, Erik, Pahl-Wostl, Claudia, Rees, Yvonne, Searle, Brad, Tàbara, David \& Tippett, Joanne, Social learning in European river-basin management: barriers and fostering mechanisms from 10 river basins. Ecology and Society, 12(1), 2007.

[16] Tippett, J., Searle, B., Pahl-Wostl, C. \& Rees, Y., Social learning in public participation in river basin management - early findings from HarmoniCOP European case studies. Environmental Science \& Policy 8 (3): pp. 287-299, 2005.

[17] Welp, M., The use of decision support tools in participatory river basin management. Physics and Chemistry of the Earth, Part B: Hydrology, Oceans and Atmosphere 26 (7): pp. 535-539, 2001.

[18] Dunlap, R.E., Trends in public opinion toward environmental issues: 19651990. Society \& Natural Resources, 4: pp. 285-312, 1991.

[19] Salent, P., \& Dillman, D., How to Conduct your own Survey. John Wiley and Sons, Inc. New York, New York, 1994.

[20] Dillman, D., Mail and Internet Surveys: The Tailored Design Method. John Wiley and Sons, Inc. New York, New York, 2000.

[21] SAS Institute Inc., SAS Online Document 9.1.3. Cary, North Carolina: SAS Institute Inc., 2004. 